\title{
Peningkatan Karakteristik Traksi Pada Mobil Formula Sapuangin Speed 3
}

\author{
Nursaid Eko Wibowo, dan I Nyoman Sutantra \\ Jurusan Teknik Mesin, Fakultas Teknologi Industri, Institut Teknologi Sepuluh Nopember (ITS) \\ Jl. Arief Rahman Hakim, Surabaya 60111 Indonesia \\ e-mail: tantra@me.its.ac.id
}

\begin{abstract}
Abstrak - Melihat hasil Student Formula Japan 2015, capaian dynamict event dari ITS team sapuangin sangatlah kurang. Pada dynamic event yang meliputi: acceleration, skidpad, autocross dan endurance ITS team Sapuangin hanya mengikuti 2 event. Catatan hasil waktu yang diperoleh juga sangatlah kurang, rata-rata terpaut 7 second sampai 10 second dari para juara. Hal ini menunjukkan kurangnya kemampuan mobil untuk bermanuver. Salah satu faktor yang mempengaruhi adalah kinerja dari kendaraan dimana gaya dorong/traksi sebagai parameter. Dalam penelitian ini dilakukan peningkatan karakteristik traksi pada mobil formula Sapuangin Speed 3 yang menggunakan mesin husaberg 450 cc dengan 6 tingkat kecepatan. Langkah pertama harus mengetahui karakteristik mesin husaberg $450 \mathrm{cc}$, kemudian dilakukan analisa untuk memilih parameter yang tepat. Setelah itu ditentukan rancangan peningkatan traksi kendaraan yaitu dengan cara merubah final drive dan diameter velg serta perancangan rasio transmisi ulang apabila diperlukan. Selain itu dilakukan juga analisa traksi saat belok yang berhubungan dengan pengaruh pemakaian Limitted Slip Differential (LSD) pada mobil sapuangin speed 3 terhadap radius belok lintasan. Dari hasil penelitian, untuk meningkatkan karakteristik transmisi tanpa mengubah rasio dipilih mengganti sprocket menjadi 56 dan velg 13 dengan estimasi waktu tempuh akselerasi 4.63 s. Sedangkan untuk meningkatkan karakteristik traksi dengan mengubah rasio mobil sapuangin speed 3 dipilih menggunakan sprocket 52, velg 15, dengan 7 tingkat kecepatan, estimasi waktu tempuh akselerasi 4.16 second dengan penambahan negative wing pada bagian belakang untuk melawan spin. Untuk pengaruh pemakaian LSD pada mobil mengakibatkan mobil susah dikendalikan dan cenderung merugikan, torsi/putaran roda dalam dan roda luar cenderung sama ketika belok, namun pada kenyataanya kebutuhan torsi/putaran roda berbeda.
\end{abstract}

Kata kunci - Sapuangin Speed 3, traksi/gaya dorong, spin, percepatan maksimum, Limitted Slip Differential (LSD).

\section{PENDAHULUAN}

$\mathrm{P}$ ada mobil formula Sapuangin Speed 3 yang berlaga pada tahun 2015 terdapat beberapa kesalahan perhitungan dimensi kokpit sehingga perlu diperbaiki dulu. Hal ini berakibat lamanya proses technical inspection, akibatnya mobil Sapuangin Speed 3 hanya mampu mengikuti 2 event yaitu skidpad dan endurance. Pada tugas akhir ini akan dievaluasi kemampuan mobil sapuangin speed dalam berakselerasi. Uji coba yang telah dilakukan pada 75 meter jarak tempuh mendapatkan waktu 4.8 detik. Hasil ini ternyata masih jauh dari kinerja juara yang hanya membutuhkan 4.1 detik pada lintasan yang sama. Untuk itu perlu dilakukan analisa pada sistem transmisi dan final drive untuk menghitung perbandingan yang tepat demi meningkatkan performa mobil saat uji akselerasi. Salah satu faktor yang mempengaruhi adalah kinerja dari kendaraan dimana gaya dorong/traksi sebagai parameter.

Kendala lain yang dihadapi selama perlombaan adalah kendaraan mengalami understeer dan oversteer. Pada kecepatan dan radius belok yang konstan, mobil sapuangin speed 3 cenderung mengalami understeer atau sulit dibelokkan. Sedangkan pada saat akselerasi ketika berbelok mobil cenderung mengalami oversteer atau roda belakang mobil terbuang keluar sehingga menyebabkan sulit untuk dikendalikan. Pada dasarnya suatu mobil akan mudah berbelok yaitu dengan distribusi putaran roda yang sesuai dengan radius beloknya. Putaran roda dalam dan luar haruslah berbeda, apabila roda dalam dan luar berputar dengan putaran sama, maka salah satu ban akan slip, terseret dan menyebabkan akan cepat aus. Untuk mengatasi hal tersebut diperlukan pembagi daya yaitu differential gear dengan tujuan membedakan putaran roda.

Pada mobil Sapuangin Speed 3 menggunakan pembagi daya Limited Slip Differential (LSD). LSD adalah salah satu alat yang bisa menunjang untuk memaksimalkan traksi. LSD kurang lebih sama seperti Open Differential (gardan biasa), tetapi pada kondisi roda yang memiliki traksi rendah LSD mampu mentransfer torsi lebih dari open differential. Teori limited slip adalah factor locking dalam presentase, seberapa banyak torsi yang diberikan dapat diteruskan hanya pada satu poros [1]. Pada kenyataanya saat berbelok mobil Sapuangin Speed 3 cenderung mengalami understeer hal ini dikarenakan putaran roda dalam dan kanan cenderung sama. .

Dalam tugas akhir ini, dilakukan analisa tentang peningkatan traksi/gaya dorong kendaraan pada mobil formula Sapu Angin Speed 3 pada lintasan lurus dan belok. Selain itu dilakukan juga analisa traksi saat belok yang berhubungan dengan pengaruh pemakaian Limitted Slip Differential (LSD) pada mobil sapuangin speed 3 terhadap radius belok lintasan agar dalam perancangan mobil baru untuk kompetisi selanjutnya lebih baik dalam bermanuver.

\section{URAIAN PENELITIAN}

Pada penulisan tugas akhir ini, prosedur penelitian dilakukan dengan beberapa tahapan yang akan dilakukan sebagai berikut: 
* Tahap awal, melakukan analisa - analisa dengan sumber studi literatur terhadap buku, jurnal dan penelitian terdahulu tentang perilaku traksi/gaya dorong kendaraan.

* Tahap selanjutnya adalah penentuan objek mobil yang akan diteliti, dalam hal ini mobil yang akan diteliti adalah mobil formula Sapuangin Speed 3 untuk kompetisi Student Formula Japan 2015.

* Tahap ketiga, setelah didapat rancangan data spesifikasi dari kendaraan formula Sapuangin Speed 3 selanjutnya dilakukan analisa peningkatan karakteristik traksi.

A. Menganalisa Karakteristik Traksi Mesin Husaberg 450 cc Standar

Untuk menghitung gaya dorong pada roda penggerak $(\mathrm{Ft})$ dengan memperhatikan efisiensi ( $\eta t)$ pada semua proses transmisi dirumuskan sebagai berikut [2] :

$$
F t=\frac{i t \cdot i g \cdot M e}{r} \eta t
$$

Dimana:

$$
\begin{aligned}
\mathrm{Me} & =\text { torsi keluaran dari mesin (N.m) } \\
\eta \mathrm{t} & =\text { efisiensi transmisi }
\end{aligned}
$$

(0.88-0.92) untuk mesin yang letaknya memanjang, poros penggerak belakang

(0.91-0.95) untuk mesin yang letaknya melintang

it $\quad=$ perbandingan gigi transmisi

ig = perbandingan transmisi pada gardanr $=$ radius ban

Gaya hambat total pada kendaraan adalah :

$$
\text { Rtotal }=R a+R r
$$

Dimana $: \mathrm{Ra}=$ habatan aerodinamik $(\mathrm{N})$

$$
\mathrm{Rr}=\text { hambatan rolling }(\mathrm{N})
$$

Untuk menghitung pengaruh gaya hambat rolling pada kendaraan dapat menggunakan rumus:

$$
\begin{aligned}
& f r=f o+f s\left(\frac{V k}{100}\right)^{2,5} \\
& R r r=f r x(W f+W r)
\end{aligned}
$$

Dimana, fr $\quad=$ koefisien hambat rolling

fo dan fs =koefisien tergantung pada tekanan ban

$\mathrm{Vk}=$ Kecepatan pada tingkat $\mathrm{k}(\mathrm{km} / \mathrm{h})$

Rrr = gaya hambat ressistance pada roda belakang $(\mathrm{N})$

Wf = berat roda depan $(\mathrm{N})$

$\mathrm{Wr} \quad=$ berat roda belakang $(\mathrm{N})$

Untuk menghitung pengarug gaya hambat aerodinamika menggunakan rumus sebagai berikut:

$$
R a=\frac{1}{2} x \rho x C d x \text { Af } x V^{2}
$$

Dimana, $\mathrm{Ra}=$ hambatan aerodinamika $(\mathrm{N})$

$$
\begin{aligned}
& \mathrm{P}=\text { massa jenis }\left(\mathrm{kg} / \mathrm{m}^{3}\right) \\
& \mathrm{Cd}=\text { koefisien drag } \\
& \mathrm{Af}=\text { Luas frontal area }\left(\mathrm{m}^{2}\right) \\
& \mathrm{V}=\operatorname{kecepatan}(\mathrm{m} / \mathrm{s})
\end{aligned}
$$

B. Menghitung Kecepatan dan Percepatan Kendaraan

Kecepatan maksimum kendaran dalam setiap tingkat transmisi (k) dapat dirumuskan:
$V k=\frac{\text { Rpmoutput engine }}{i k \times i g} \times \frac{2 \pi}{60} \times$ jari - jari roda belakang $\times \frac{3600}{1000}$

Dimana : Vk $=$ kecepatan pada tingkat $\mathrm{k}(\mathrm{km} / \mathrm{h})$

$$
\begin{aligned}
& \mathrm{Ik}=\text { rasio transmisi pada tingkat } \mathrm{k} \\
& \mathrm{Ig}=\text { rasio garden }
\end{aligned}
$$

- Untuk kondisi percepatan, kendaran diam mencapai kecepatan akhir $(\mathrm{Vt})$

$$
\begin{aligned}
& a=\frac{V t^{2}}{2 . S}=\frac{V t}{t}=\frac{2 . S}{t^{2}} \\
& t=\frac{V t}{a}=\frac{2 . S}{V t}=\sqrt{\frac{2 . S}{a}} \\
& S=\frac{V t^{2}}{2 . a}=\frac{V t . t}{2}=\frac{2 . t^{2}}{2}
\end{aligned}
$$

- Sedangakan untuk mencari percepatan untuk setiap tingat gigi (k), dapat dirumuskan sebagai berikut:

$$
a_{k}=\frac{(F t-R r r-R a)}{\text { massa penuh }}
$$

Dimana: a $=$ percepatan $(\mathrm{m} / \mathrm{s})$

$\mathrm{Ft}$ = gaya dorong $(\mathrm{N})$

Rrr = gaya hambat ressistance pada roda belakang (N)

$\mathrm{Ra}=$ hambatan aerodinamika $(\mathrm{N})$

\section{Menghitung Rasio Baru}

Salah satu cara untuk mencari perbandingan gigi antara tingkat transmisi terendah dan tertinggi adalah dengan cara progresi geometris [2]:

$$
\begin{aligned}
& \frac{i 2}{i 1}=\frac{i 3}{i 2}=\frac{i 4}{i 3}=\frac{n e 2}{n e 1}=K g \\
& \left(\frac{i_{m}}{i_{1}}\right)^{\frac{1}{n-1}}=k g
\end{aligned}
$$

Dimana :

I1, i2, i3, i4 = rasio gigi pada tingkat transmisi

$$
\begin{array}{ll}
\mathrm{Im} & =\text { rasio gigi terakhir } \\
\mathrm{Kg} & =\text { konstanta perbandingan }
\end{array}
$$

Untuk mencari rasio gigi awal dan terakhir dapat menggunakan rumus berikut [2]:

- Untuk kebutuhan gaya dorong F1 dan Rasio tingkat satu:

$$
\begin{gathered}
F 1=\frac{W}{g} a+R r+R a \\
i_{1}=\frac{\left(\frac{w}{g} a+f r \cdot W+R a\right) \cdot r}{M e . i_{g} \cdot \eta t}
\end{gathered}
$$

- Untuk kebutuhan gaya dorong (Fm) pada kecepatan maksimum $(\mathrm{Vm})$, dan rasio tingkat akhir $(\mathrm{im})$ :

$$
\begin{aligned}
F m & =R r+R a=f r \cdot W+\frac{1}{2} \rho \cdot C_{D} \cdot A_{f} \cdot(V m)^{2} \\
i_{m} & =\frac{F m \cdot R}{M e . i_{g} \eta_{t}}
\end{aligned}
$$

\section{Menganalisa kebutuhan Torsi dan Kecepatan Roda Saat Belok}

Apabila roda dalam dan luar berputar dengan putaran sama, maka salah satu ban akan slip, terseret dan menyebabkan akan cepat aus. Untuk mengatasi hal tersebut diperlukan differential gear dengan tujuan membedakan putaran roda. Cara menghitung putaran roda dalam maupun luar pada saat 
berbelok adalah dengan menggunakan rumus sebagai berikut: rasio \% lock roda $a_{\text {dalam,luar }} \geq\left[\frac{n_{i}}{n_{0}}=\frac{R_{i}}{R_{0}}\right]$

Keterangan: $n_{i}=$ putaran roda dalam

$n_{o}=$ putaran roda luar

$R_{i}=$ jarak sumbu putar roda dalam dengan pusat radius belok

$R_{o}=$ jarak sumbu putar roda luar dengan pusat radius belok

Untuk mengetahui pengaruh sudut belok rata-rata terhadap torsi roda dapat menggunakan rumus sebagai berikut [1] :

- Gaya normal roda dalam saat belok

$$
F z i=\frac{W r}{2}-\frac{\frac{a}{a+b} F c \cos \delta \cdot h r}{t r}-\frac{\frac{a}{a+b}(F c \cos \delta \cdot r c+W \cdot r c \cdot \gamma}{t r}
$$

- Gaya normal roda luar saat belok

$$
\begin{gathered}
F z O=\frac{W r}{2}+\frac{\frac{a}{a+b} F c \cos \delta \cdot h r}{t r}+\frac{\frac{a}{a+b}(F c \cos \delta \cdot r c+W \cdot r c \cdot \gamma}{t r} \\
F C=m \cdot \omega^{2} \cdot R_{a c k}
\end{gathered}
$$

- Gaya dorong/traksi roda:

$$
F t=F z \cdot \mu
$$

- Torsi roda :

$$
T=F t . R_{\text {roda }}
$$

- Kecepatan roda:

$$
\begin{aligned}
& V=\omega \cdot R \\
& \omega=\frac{2 \pi}{t}
\end{aligned}
$$

Keterangan:

$\mathrm{Fz}$ = Gaya normal saat belok $(\mathrm{N})$

$\mathrm{Wr}=$ Berat roda belakang $(\mathrm{N})$

$\mathrm{Fc}=$ Gaya sentrifugal $(\mathrm{N})$

$\omega=$ kecepatan sudut $\mathrm{roda}(\mathrm{rad} / \mathrm{s})$

$\mathrm{R}=$ jarak pusat lingkaran lintasan menuju roda $(\mathrm{m})$

$R_{\text {roda }}=$ Jari-jari roda $(\mathrm{m})$

$\mathrm{T}=$ Torsi roda $(\mathrm{Nm})$

$\mathrm{Ft}=\operatorname{trasksi} \operatorname{roda}(\mathrm{N})$

$\mathrm{V}=$ Kecepatan $\operatorname{roda}(\mathrm{m} / \mathrm{s})$

$\operatorname{Tr}=$ Trackwidth belakang kendaraan $(\mathrm{m})$

$\mathrm{T}=$ waktu tempuh (s)

\section{E. Limitted Slip Differential}

Pada umumnya LSD dibagi menjadi 3 sistem yaitu 1 way, 1.5 way, dan 2 way. Berikut adalah penjelasan mengenai mekanisme dari ketiga sistem:

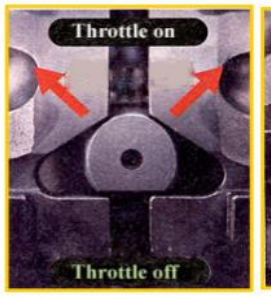

1 way Gambar 1 Mekanisme aktivasi LSD [5]
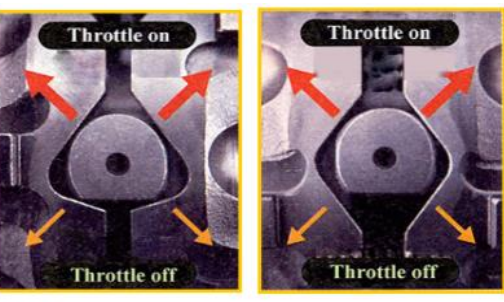

2 way
Keterangan :

1. 1 way

LSD 1 way hanya aktif/lock ketika throttle on atau akseleras

2. 1.5 way
LSD 1.5 way aktif/lock saat akselerasi dan $50 \%$ saat dekselerasi

3. 2 way

LSD 2 way aktif/lock $100 \%$ lock saat akselrasi maupun dekselerasi.

\section{HASIL DAN ANALISA}

\section{A. Grafik Karakteristik Mesin Husaberg 450cc}

Untuk mengetahui karakteristik traksi sebuah mesin, terlebih dahulu kita harus mengetahui nilai daya maupun torsi real/sebenarnya dari mesin tersebut, maka perlu dilakukan dynotest. Setelah dilakukan dynotest maka akan didapatkan karakteristik mesin husaberg 450 cc. Berikut adalah hasil perhitungannya:

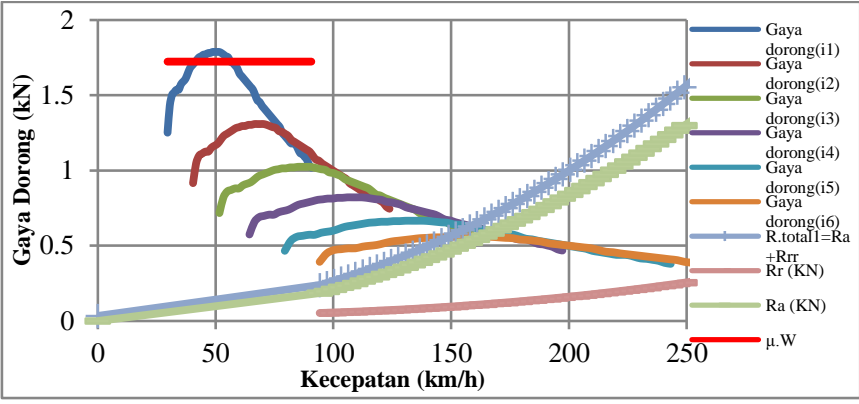

Gambar 2 Grafik karakteristik mesin $450 \mathrm{cc}$ standar sprocket 52

Untuk tingkat gigi 1 mempunyai gaya dorong maksimum sebesar $1.79 \mathrm{kN}$, gigi 2 sebesar $1.3 \mathrm{kN}$, gigi 3 sebesar $1.03 \mathrm{kN}$, gigi 4 sebesar $0.82 \mathrm{kN}$, gigi 5 sebesar $0.67 \mathrm{kN}$, dan gigi 6 sebesar $0.56 \mathrm{kN}$. Sedangkan perkalian nilai $\mu$.W (spin area) sebesar $1.72 \mathrm{kN}$ berada pada gigi 1 memotong kurva gaya dorong 1. Untuk kecepatan maksimum kendaran dapat dilihat dari perpotongan kurva hambatan total dan gaya dorong gigi 6 sebesar $155 \mathrm{~km} / \mathrm{h}$. Dengan kondisi mesin standar, gaya dorong maksimum $1.79 \mathrm{kN}$, kecepatan maksimum kendaraan 155 $\mathrm{km} / \mathrm{h}$, percepatan maksimum rata-rata $5.9 \mathrm{~m} / \mathrm{s}^{2}$ dan akan mengalami spin pada rpm 4400-5800 pada gigi1.

\section{B. Perbandingan Sprocket 48,52,56 Pada Mesin Standar dengan Rim velg R13}

Salah satu cara untuk meningkatkan gaya dorong / traksi kendaraan dapat melalui sistem transmisi dan final drive. Maka dipilih pergantian final drive yaitu sprocket menjadi 48, 52, dan 56.

Melihat hasil perbedaan grafik 2, 3, dan 4 dengan pergantian final drive sprocket 48, 52, 56 yaitu bagian gaya dorong maksimum tiap gigi/percepatan dan kecepatan maksimum, dengan perubahan final drive sprocket pun masih belum memenuhi kebutuhan gaya dorong dan percepatan kendaraan. 


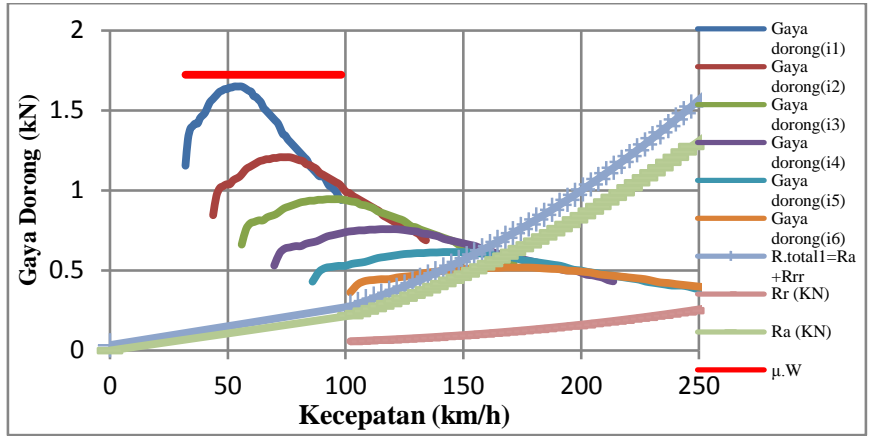

Gambar 3. Grafik gaya dorong terhadap kecepatan dengan sprocket 48 rim velg 13

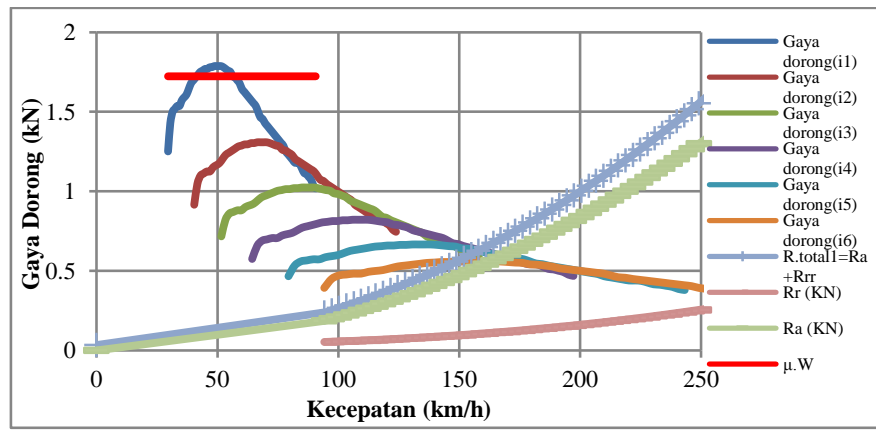

Gambar 4. Grafik gaya dorong terhadap kecepatan dengan sprocket 52 rim velg 13

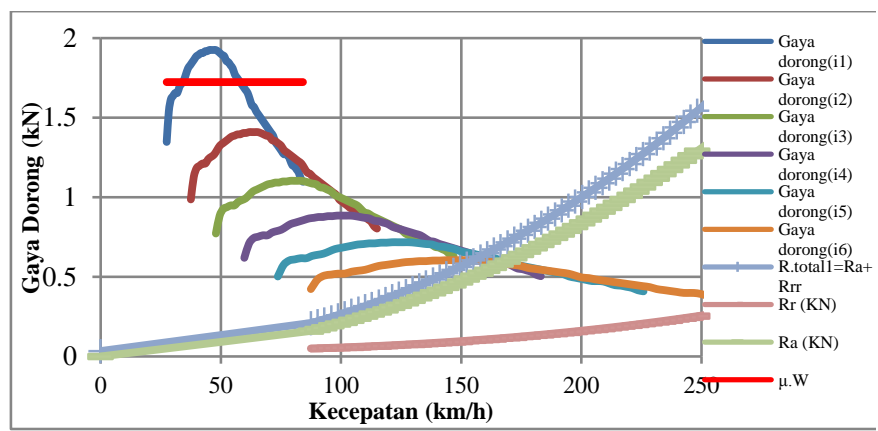

Gambar 5. Grafik gaya dorong terhadap kecepatan dengan sprocket 56 rim velg 13

Begitu juga dengan adanya spin akan merugikan, banyak traksi yang terbuang percuma. Untuk menghindari hal tersebut yang perlu diperhatikan adalah cara mengemudi driver. Driver harus bisa merasakan kapan mobil akan terjadi spin pada saat gigi 1, untuk itu perlakuannya cukup half throttle dan percepatan harus konstan artinya pedal gas tidal boleh diinjak dengan tiba-tiba melainkan harus perlahan dengan percepatan konstan sampai batas kecepatan maksimum atau torsi maksimum. Batas kecepatan atau torsi maksimum adalah sesaat sebelum terjadinya spin. Sebelum mencapai batas tersebut driver sudah harus mengganti ke gigi 2 dan seterusnya. Untuk gigi 2 dan seterusnya harus full throttle sampai batas kecepatan/ torsi maksimum. Selain itu salah satu cara untuk mengurangi atau menghilangkan adalah dengan cara menggeser posisi titik berat lebih ke belakang dan mengganti diameter roda yang lebih besar.

\section{Perbandingan Sprocket 48,52,56 pada Mesin Standar dengan Rim velg 15}

Salah satu cara untuk menghilangkan spin adalah menggati diameter roda yang lebih besar yang awalnya menggunakan rim velg 13 akan diubah menjadi velg rim 15 . Berikut adalah grafikgrafik karakteristik mesin husaberg $450 \mathrm{cc}$ ketika digunakan sprocket dengan gigi 48, 52, dan 56 dengan rim velg 15 :

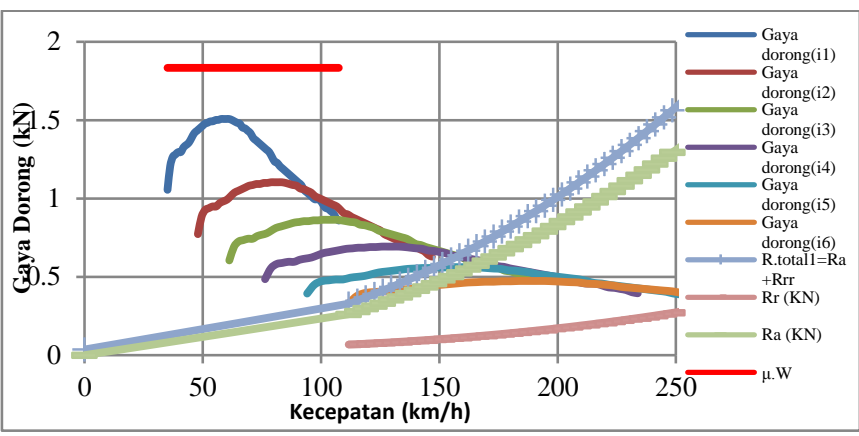

Gambar 6. Grafik gaya dorong terhadap kecepatan dengan sprocket 48 rim velg 15

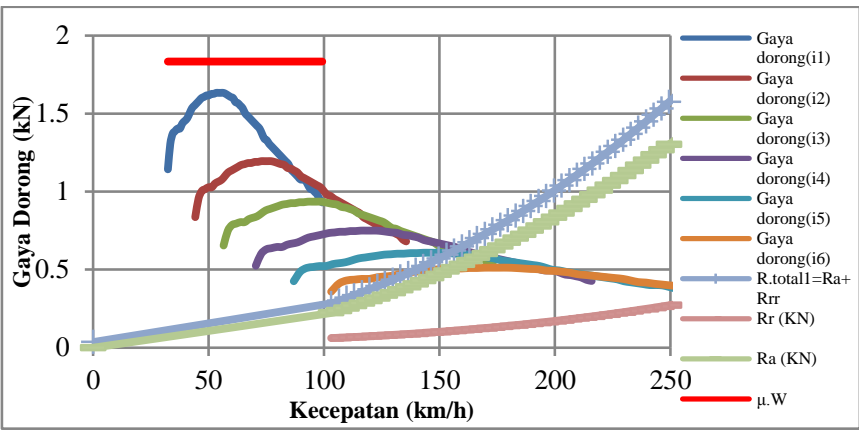

Gambar 7. Grafik gaya dorong terhadap kecepatan dengan sprocket 52 rim velg 15

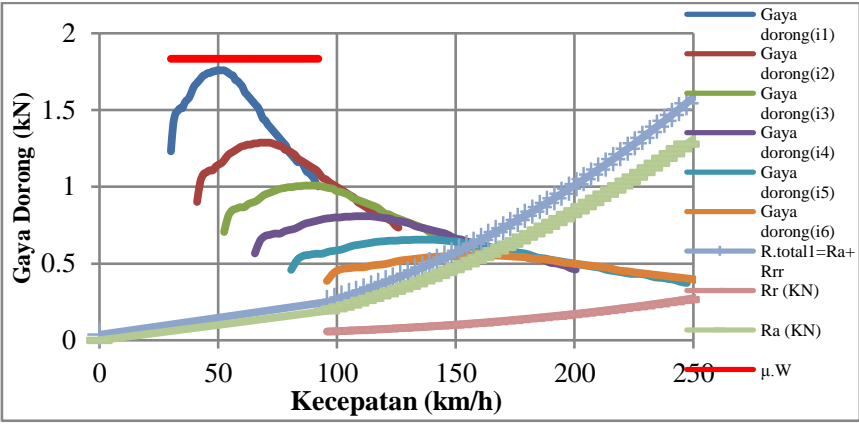

Gambar 8. Grafik gaya dorong terhadap kecepatan dengan sprocket 56 rim velg 15

Melihat hasil perbedaan grafik 4, 5, dan 7 dengan pergantian final drive sprocket 48, 52, 56 velg 15 yaitu bagian gaya dorong maksimum tiap gigi/percepatan dan kecepatan maksimum. Untuk penggunaan diameter velg 15 tidak akan mengalami spin pada roda belakang tetapi untuk percepatannya akan berkurang karena efek dari momen inersia roda diawal pada gigi 1 , akibatnya perolehan waktu lebih besar dengan velg 13 dari pada velg 15 .

D. Perbandingan Karakteristik Transmisi Tingkat 1, 2 dan 3

Rasio Standar Menggunakan Sprocket 52 Rim Velg 13 dan Velg 15 
Pada realitanya saat acceleration test mobil Sapuangin speed 3 hanya sampai tingkat transmisi 3 untuk mencapai lintasan sejauh 75 meter. Oleh karena itu analisa perbandingan tingkat transmisi hanya dilakukan sebutuhnya.

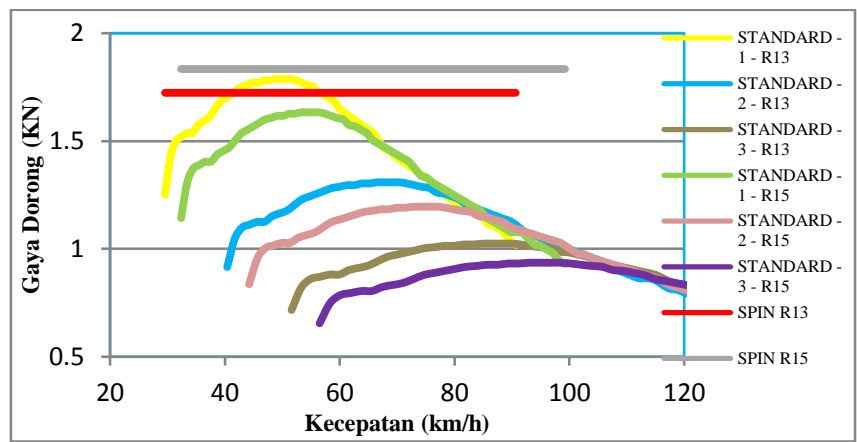

Gambar 9. Grafik perbandingan karakteristik transmisi tingkat 1,2 dan 3 rasio standar sprocket 52 velg 13 dan velg 15

Untuk tingkat 1 mempunyai gaya dorong maksimum pada rasio standar sprocket 52 velg 13 sebesar $1,79 \mathrm{kN}$ sedangkan velg 15 sebesar $1.63 \mathrm{kN}$. Tingkat 2 mempunyai gaya dorong maksimum pada rasio standar sprocket 52 velg 13 sebesar 1,31 $\mathrm{kN}$ sedangkan velg 15 sebesar $1.19 \mathrm{kN}$. Sedangkan tingkat 3 mempunyai gaya dorong maksimum pada rasio standar sprocket 52 velg 13 sebesar $1,03 \mathrm{kN}$ sedangkan velg 15 sebesar $0.94 \mathrm{kN}$. Kecepatan optimum pada tingkat 1 rasio standar sprocket 52 velg 13 mencapai $41.03 \mathrm{~km} / \mathrm{h}$, dan velg 15 mencapai $53.27 \mathrm{~km} / \mathrm{h}$. Pada tingkat 2 rasio standar sprocket 52 velg 13 mencapai $66.48 \mathrm{~km} / \mathrm{h}$, dan velg 15 mencapai 72.78 $\mathrm{km} / \mathrm{h}$. Sedangkan pada tingkat 3 rasio standar sprocket $52 \mathrm{velg}$ 13 mencapai $84.92 \mathrm{~km} / \mathrm{h}$, dan velg 15 mencapai $92.96 \mathrm{~km} / \mathrm{h}$.

Setelah mengetahui nilai kecepatan dan percepatan pada setiap tingkat maka dapat dihitung estimasi waktu tempuh.

$$
\text { Tabel } 1 .
$$

Tabel perhitungan waktuh tempuh akselerasi

\begin{tabular}{rcccc}
\hline \multicolumn{5}{c}{ STANDAR } \\
\hline R13 & $\begin{array}{l}\text { V max } \\
\text { (1) }\end{array}$ & $\begin{array}{l}\text { V max } \\
(2)\end{array}$ & \multicolumn{1}{c}{ V max } & waktu \\
km/h & & akselerasi (s) \\
sprocket 48 & 52.72 & 72.02 & 91.99 & 4.75 \\
sprocket 52 & 41.03 & 66.48 & 84.92 & 4.69 \\
sprocket 56 & 33.67 & 61.73 & 78.85 & 4.63 \\
R15 & V max & V max & V max & waktu \\
& $(1)$ & $(2)$ & $(3)$ & akselerasi (s) \\
sprocket 48 & 57.71 & 78.84 & 100.70 & 4.97 \\
sprocket 52 & 53.27 & 72.78 & 92.96 & 4.91 \\
sprocket 56 & 43.65 & 67.58 & 86.32 & 4.84 \\
\hline \hline
\end{tabular}

Dari hasil pencapaian pergantian sprocket dan diameter velg belum mencapai target, lebih cepat dari tim juara yaitu tim dari Graz University dengan capaian waktu 4.19 s. Selanjutnya untuk meningkatan traksi dapat dilakukan juga dengan merancang ulang rasio transmisi.

\section{E. Perbandingan tingkat rasio 5,6,7}

Setelah mengubah gigi sprocket dan diameter velg, kebutuhan percepatan maksimum sebesar $\mathrm{a}=9 \mathrm{~m} / \mathrm{s}^{2}$ masih belum terpenuhi oleh karena itu dilakukan perhitungan rasio ulang.
Berikut adalah grafik karakteristik dengan tingkat rasio 5, 6, dan 7:

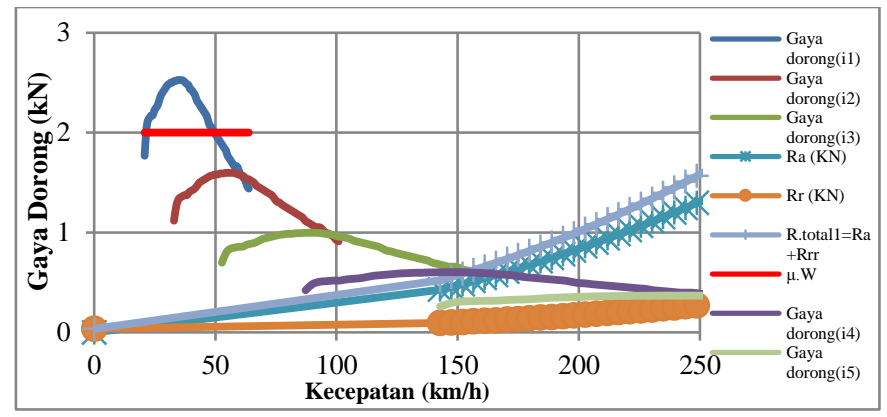

Gambar 10 Grafik gaya dorong terhadap kecepatan dengan rasio baru 5 tingkat

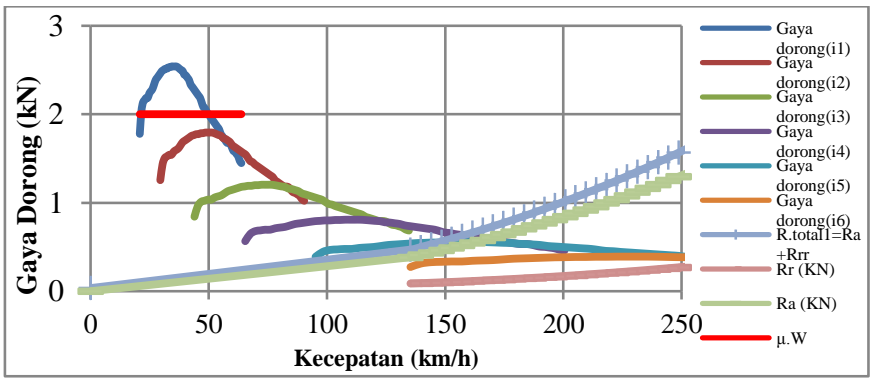

Gambar 11. Grafik gaya dorong terhadap kecepatan dengan rasio baru 6 tingkat

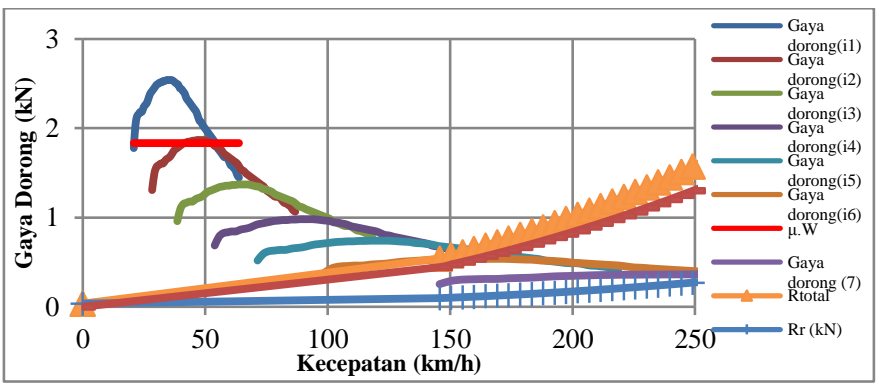

Gambar 12. Grafik gaya dorong terhadap kecepatan dengan rasio baru 7 tingkat

Pada grafik 7, 8, dan 9 untuk ketiga tingkat juga mengalami spin yang merugikan performa kendaraan yaitu terbuangnya traksi dengan sia-sia. Untuk mengatasi hal tersebut diperlukan komponen aerodinamik yaitu Negative Wing (Spoiler) dibagian belakang guna membantu melawan spin dengan menambah gaya berat. Selain itu komponen aerodinamik yang lain yang mungkin digunakan untuk meningkatkan performa adalah Traction Control. Komponen ini berfungsi untuk mengatur traksi pada roda sesuai dengan hambatan gesek yang diterima, sehingga roda tidak akan mengalami spin pada $\mathrm{rpm} /$ kecepatan berapapun.

Tabel 2.

Perhitungan gaya dorong dan kecepatan dengan perubahan rasio dan sprocket

\begin{tabular}{clccc}
\hline \hline No & Variasi & $\begin{array}{c}\text { Ft max } \\
(\mathrm{KN})\end{array}$ & $\begin{array}{c}\mathrm{v} \\
(\mathrm{km} / \mathrm{h})\end{array}$ \\
\hline 1 & & & \\
& $\begin{array}{l}\text { Penggantian sproket pada kondisi } \\
\text { standar velg 13 }\end{array}$ & & \\
& rasio & sproket 48 & 1.65 & 158 \\
& standar & sproket 52 & 1.79 & 155 \\
& & sproket 56 & 1.93 & 150 \\
\hline \hline
\end{tabular}


2 Penggantian sproket pada kondisi standar velg 15

\begin{tabular}{|c|c|c|c|c|}
\hline rasio & & & 1.50 & 160 \\
\hline standar & & & 1.63 & 158 \\
\hline & & & 1.76 & 155 \\
\hline $\begin{array}{l}\text { Penggantiar } \\
\text { baru velg } 1\end{array}$ & asio sprok & asio & & \\
\hline rasio baru & 5 tingkat & 48 & 2.34 & 158 \\
\hline & & 52 & 2.54 & 155 \\
\hline & & 56 & 2.74 & 153 \\
\hline & 6 tingkat & 48 & 2.34 & 160 \\
\hline & & 52 & 2.54 & 158 \\
\hline & & 56 & 2.74 & 156 \\
\hline & 7 tingkat & 48 & 2.34 & 162 \\
\hline & & 52 & 2.54 & 160 \\
\hline & & 56 & 2.74 & 158 \\
\hline
\end{tabular}

F. Pengaruh Limitted Slip Differential (LSD)

Untuk mengetahui torsi roda dan kecepatan roda dapat dihitung menggunakan rumus 2.16 dan 2.17. Gambar 4.13 adalah grafik pengaruh torsi roda $(\mathrm{T})$ terhadap sudut belok ratarata $(\delta)$ mulai dari 1 derajat sampai 30 derajat

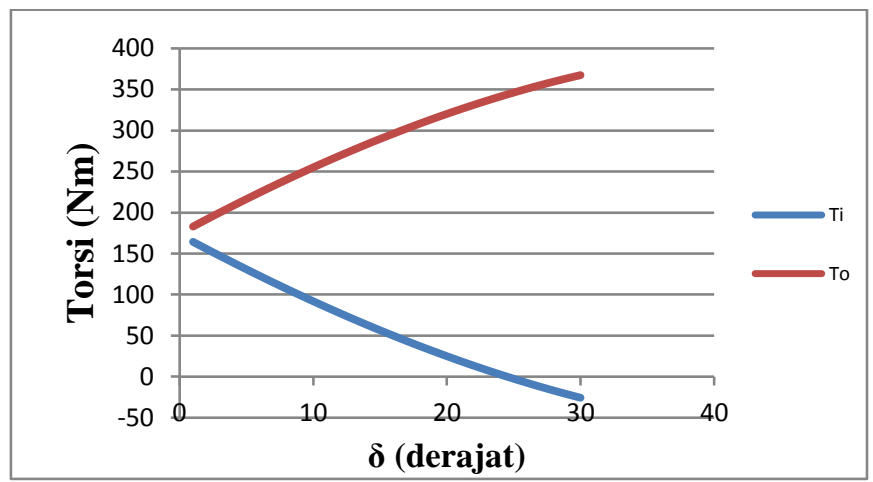

Gambar 13. Grafik pengaruh sudut belok rata-rata $(\delta)$ terhadap torsi roda $(\mathrm{T})$

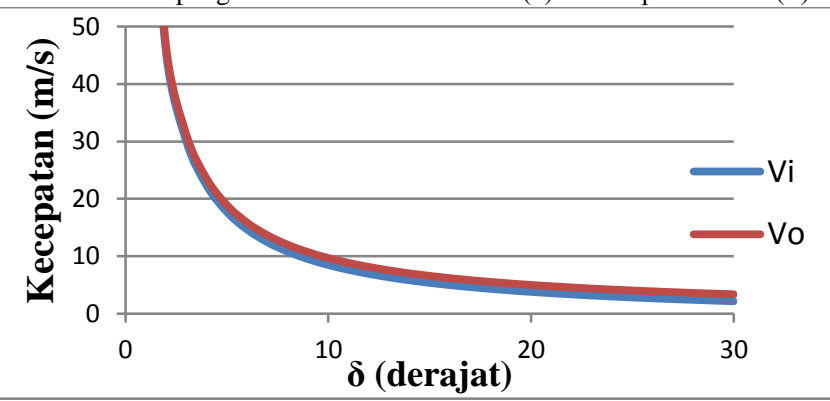

Gambar 14. Grafik pengaruh sudut belok rata-rata $(\delta)$ terhadap V

Melihat grafik hasil perhitungan diatas,untuk grafik 10 semakin besar sudut belok rata-rata atau radius belok semakin kecil, maka semakin besar perbandingan torsi yang mampu diterima roda dalam maupun luar. Sedangkan grafik 11 semakin besar sudut belok rata-rata atau radius belok semakin kecil, maka semakin besar perbandingan atau perbedaan kecepatan roda dalam dan luar. Artinya semakin besar perbandingan locking roda dalam dan luar dalam penggunaan LSD.

Untuk skidpad dengan sudut belok rata-rata 10 derajat dibutuhkan torsi roda dalam dan luar dengan rasio 0.87 yang artinya torsi roda dalam sama dengan 0.87 kali torsi roda luar $(\mathrm{To}=0.87 \mathrm{To})$. Hal ini sangat berbeda ketika menggunakan LSD, torsi roda dalam dan luar saat belok cenderung sama.

\section{KESIMPULAN}

Setelah melakukan analisa perhitungan dan pembahasan didapatkan kesimpulan sebagai berikut:

1. Karakteristik transmisi mobil sapuangin speed 3 standar speocket 52 velg 13 untuk tingkat gigi 1 mempunyai gaya dorong maksimum sebesar $1.79 \mathrm{kN}$. Percepatan maksimum $=5.9 \mathrm{~m} / \mathrm{s}^{2}$, kecepatan maksimum $=155 \mathrm{~km} / \mathrm{h}$, dan nilai $\mu \mathrm{W}$ (spin area) sebesar $1.72 \mathrm{kN}$ akan mengalami spin pada rpm 4400-5800 pada gigil dan estimasi waktu tempuh akselerasi $4.69 \mathrm{~s}$.

2. Untuk peningkatan karakteristik transmisi tanpa mengubah rasio dipilih mengganti sprocket menjadi 56 velg 13 dengan rincian, mempunyai gaya dorong maksimum sebesar $1.93 \mathrm{kN}$, percepatan maksimum $=6.41$ $\mathrm{m} / \mathrm{s}^{2}$, kecepatan maksimum $=150 \mathrm{~km} / \mathrm{h}$, dan nilai $\mu . \mathrm{W}$ (spin area) sebesar $1.72 \mathrm{kN}$, mobil akan mengalami spin pada rpm 3900-6500 rpm pada gigi 1, estimasih waktu akselerasi $4.63 \mathrm{~s}$.

3. Semakin besar rasio final drive $\left(i_{g}\right) /$ sprocket, semakin besar pula traksi yang dihasilkan dan semakin pendek jarak kecepatan untuk perpindahan gigi. Dari grafik karakteristik transmisi dengan rasio baru, semakin banyak tingkat transmisi, semakin rapat jarak antara kurva tingkat transmisi yang berarti semakin kecil traksi yang terbuang. Untuk penggunaan diameter, semakin besar diameter semakin besar kecepatan tetapi waktu tempuh lebih besar.

4. Semakin besar sudut belok rata-rata atau radius belok semakin kecil, maka semakin besar perbandingan torsi yang mampu diterima roda dan kecepatan roda dalam dan luar.

5. Penggunaan LSD TRD sistem 1,5 way dan 2 way pada mobil sapuangin speed 3 untuk mengikuti kompetisi Student Formula Japan dapat dikatakan merugikan karena LSD akan lock bersama (kanan dan kiri) ketika akselerasi. Berbanding terbalik dengan karakteristik lintasan pada kompetisi tersebut yang penuh dengan belokan. Apabila sistem LSD lock bersama pada saat berbelok, yang artinya torsi/utaran roda dalam dan luar cenderung samam, maka kendaraan akan bergeser, sulit dibelokkan atau dapat dikatakan understeer.

\section{DAFTAR PUSAKA}

[1] Allen Jim. 2002. “ 4-Wheeler's Bible”. USA. MBI Publishing Company, 380 Jackson Street, Suite 200, St.Paul

[2] Sutantra, I Nyoman \& Bambang Sampurno. 2010. "Teknologi Otomotif : Edisi Kedua". Surabaya: Guna Widya.

[3] Tenaya I.G.N.P dan Adi Atmika, I Ketut. 2004. “ Karakteristik Traksi Dan Kinerja Transmisi Pada Sistem Gear Transmission dan Gearless Transmission". Teknik Mesin Universitas Udayana Bali.

[4] J.Y. Wong. 1978. "Theory of Ground Vehicle: $3^{\text {rd }}$ Edition". Canada. John Wiley \&n Sons,Inc.

[5] Active Traction Service. "LSD - mechanism, function, \& benefit". 14 Juni 2016. <http://www.ppi-ats.com/LSD/LSD_basics>. 